\title{
Consumption of large carcasses by scavenger assemblages in the deep Arabian Sea: observations by baited camera
}

\author{
Ursula Witte* \\ GEOMAR Research Center, Wischhofstr. 1-3, D-24148 Kiel, Germany
}

\begin{abstract}
During cruise no. 118 with RV 'Sonne' to the Arabian Sea (31 March to 10 May 1997), 2 large food fall experiments were carried out in order to study the composition of the scavenging fauna of the deep western Arabian Sea. Two shark carcasses were deployed at the sea floor at 4040 and $1900 \mathrm{~m}$ depth and monitored by a time-lapse camera for 11 and $5 \mathrm{~d}$, respectively. At $4040 \mathrm{~m}$, zoarcid fish dominated during the whole deployment period, accompanied by decapod shrimp. Decapods reached the carrion within $20 \mathrm{~min}$, and during the period monitored 1 to 4 decapods regularly occurred on or near the carcass. Single zoarcids were first observed after $5 \mathrm{~h}$, their number rising to 50-60 during the initial $48 \mathrm{~h}$, then remaining constant at this level. At $1900 \mathrm{~m}, 3$ individually identifiable deepsea stone crabs were alternately feeding on the shark carcass for most of the observation period. Fish appeared rarely and never stayed at the carcass for long. Most strikingly, giant scavenging amphipods were not observed at $1900 \mathrm{~m}$ and macrourids were not observed at $4040 \mathrm{~m}$. Not more than $20 \%$ of the carrion was consumed at both stations
\end{abstract}

KEY WORDS: Deep-sea $\cdot$ Scavenger $\cdot$ Necrophage $\cdot$ Megafauna $\cdot$ Food fall

\section{INTRODUCTION}

Scavengers are conspicious members of deep-sea megafaunal communities, and necrophages of the deep-sea have been known for over 100 yr (e.g. Chevreux 1900). Direct evidence confirmed the natural occurrence of large food falls (Heezen \& Hollister 1971, Jannasch 1978), and specialised bait-attending scavenger communities have been described from the deep Atlantic and Pacific Oceans (e.g. Stockton \& DeLaca 1982, Smith 1985, 1986, Priede et al. 1990, 1991, 1994, Thurston et al. 1995). The dominant and most readily attracted scavengers, responsible for most bait consumption and dispersal at abyssal depth, are usually lysianassid amphipods and macrourid fish. Of the latter, just 1 species, Coryphaenoides armatus,

\footnotetext{
- Present address: Max-Planck-Institute for Marine Microbiology, Celsiusstr. 1, 28359 Bremen, Germany.

E-mail: uwitte@mpi-bremen.de
}

apparently dominates the abyssal demersal fish scavenger community in the northern hemisphere, where it is invariably the first to arrive and consume bait. Below $5000 \mathrm{~m}$ in the central North Pacific it is replaced by $C$. yaquinae, which shows a very similar behaviour (Priede et al. 1991, 1994). The most conspicious baitattending amphipod is the giant lysianassid Eurythenes gryllus. It has been intensely studied and many aspects of its biology, including aspects of its feeding strategy and meal size, are known (e.g. Hessler et al. 1972, 1978, Ingram \& Hessler 1983, 1987, Hargrave 1985, Hargrave et al. 1994, 1995, Christiansen 1996). In recent years, the development of free-fall vehicles has allowed placement of artificial food falls on the sea floor for extended periods of time. Recovered remains reveal that consumption of large carcasses can be very fast: in the North Atlantic, half an Atlantic white-sided dolphin (approx. $60 \mathrm{~kg}$ of soft tissue) was skeletonized within $5 \mathrm{~d}$, and the abundant lysianassid amphipods appeared to be the main direct consumers (Jones et al. 1998). 
However, although the major components of deepsea scavenger communities attracted to large carcasses seem to be ubiquitous, striking latitudinal differences between bait-attending organisms have been described for localities at $21^{\circ} \mathrm{N}, 31^{\circ} \mathrm{N}$ and $48^{\circ} \mathrm{N}$ in the North Atlantic (Thurston et al. 1995) and have been attributed to the pattern of vertical food input. Dominance of large, macrophagous benthopelagic species at the northern locality was related to strong seasonal phytodetritus pulses that are absent at the southern localities, which are dominated by small, microphagous benthic feeding species.

Within the framework of the German joint programme BIGSET (Biogeochemical fluxes of energy and matter in the deep-sea) benthic communities in the deep Arabian Sea are being studied. This contribution presents 2 large abyssal food fall experiments carried out to study the composition and consumption rate of the scavenging fauna of the deep western Arabian Sea, a deep-sea area with a very high organic input characterised by a pronounced flux peak during the south-west monsoon (Haake et al. 1993) thos 382 deep-sea flash, 2 acoustic MORS releasers, glass spheres for buoyancy and ballast weights (for details see Priede et al. 1998). The camera was oriented vertically above the bottom and photographed an area of $1.15 \mathrm{~m}^{2}$ of seafloor. As bait, 2 white-tip sharks Charcharhinus longimanis (Poey, 1861) that had been caught in the area a few days prior to the experiments were used. Both were stored at $6^{\circ} \mathrm{C}$ until deployment. At WAST plain, a white-tip shark of $1.6 \mathrm{~m}$ length and $29 \mathrm{~kg}$ weight was deployed for $11 \mathrm{~d}$, while the Benthos camera took color photographs at intervals of $20 \mathrm{~min}$ from the beginning of the deployment until $5 \mathrm{~d} 9 \mathrm{~h}$. At WAST top, a smaller shark of $1 \mathrm{~m}$ length was deployed for $4 \mathrm{~d}$ and photographed at intervals of 10 min during the whole deployment period. Some of the skin of both sharks was removed from the dorsal surface to facilitate odour dispersal and access for scavenging organisms, and the carcasses were covered by a largemeshed net (size mesh opening $7 \mathrm{~cm}$ ) to ensure that the remains of the carcass would be recovered and that large scavengers could not tear the carcass and move it, or parts of it, out of view of the camera. At the end of the deployment, the tripod was acoustically called

\section{MATERIALS AND METHODS}

The experiments were carried out at the 2 westernmost BIGSET stations: WAST (western Arabian Sea trap) plain $\left(16^{\circ} 12^{\prime} 0 \mathrm{~N}, 60^{\circ} 16^{\prime} 0 \mathrm{E} ; 4040 \mathrm{~m}\right)$, situated at the abyssal plain, and WAST top $\left(16^{\circ} 10^{\prime} 0 \mathrm{~N}, 59^{\circ} 45^{\prime} 0 \mathrm{E}_{;} 1900 \mathrm{~m}\right)$, situated on top of a seamount approx. 30 nautical miles west of WAST plain (see Fig. 1). WAST is the location of a long-term sediment trap mooring, see e.g. Haake et al. (1993). Both stations are situated in the western Arabian Sea, where the water circulation during the SW monsoon leads to upwelling along the coast of Oman and to upward Ekman transport in offshore areas. Annual maxima of primary productivity occur at this time, leading to very high vertical flux rates of $3.2 \mathrm{~g} \mathrm{C}_{\text {org }} \mathrm{m}^{-2}$ $\mathrm{yr}^{-1}$ at $3000 \mathrm{~m}$ depth (Haake et al. 1993) and benthic carbon remineralisation rates that are up to 5 times higher than those found for other deep-sea regions (Witte unpubl.). The experiments were carried out on 21 April to 2 May 1997 (4040 m) and 3 to 5 May 1997 (1900 m), i.e. during the intermonsoon period.

A free fall vehicle was used consisting of a stainless steel tripod, equipped with a Benthos deep-sea camera 372 and Ben-

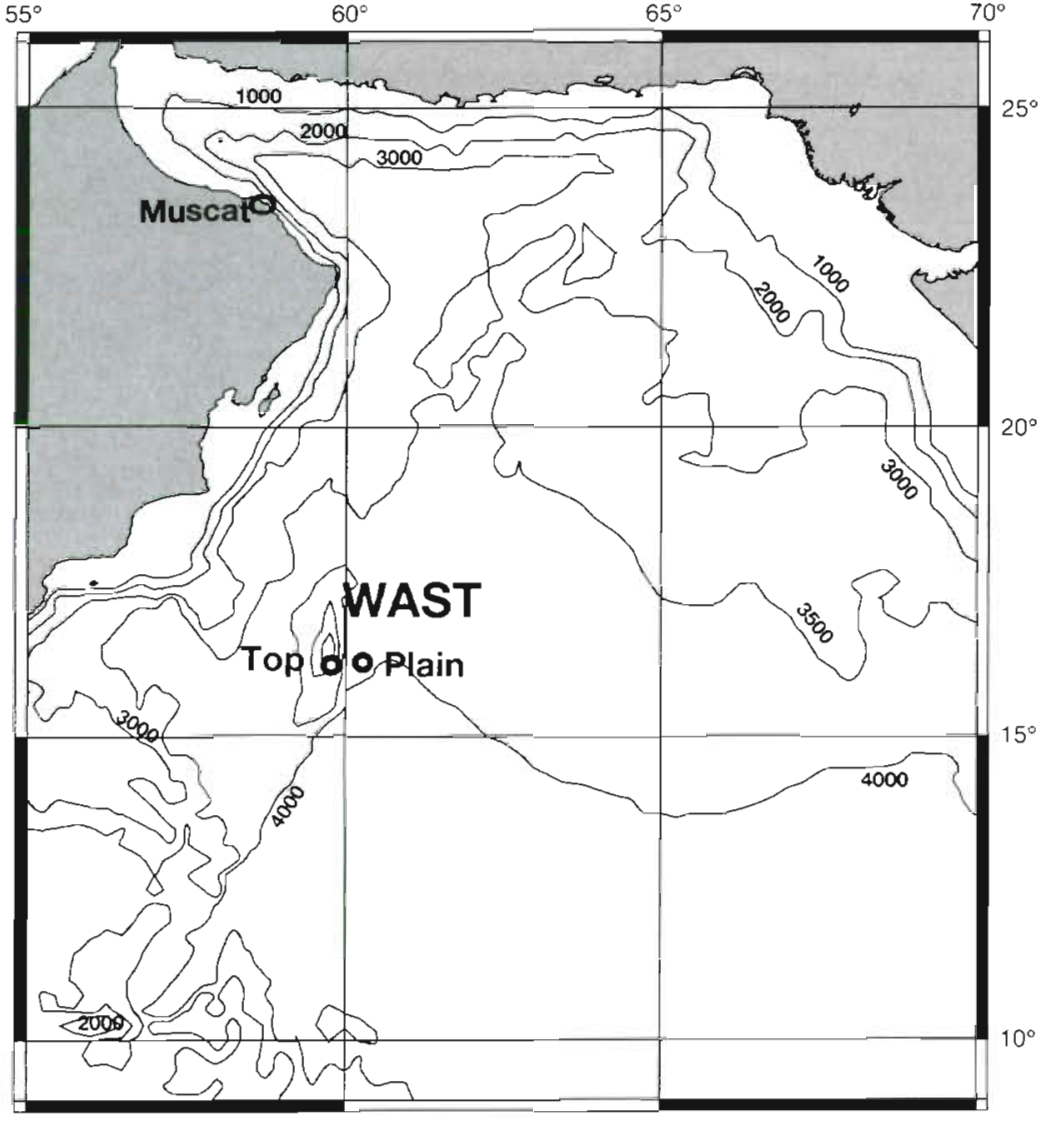

Fig. 1. Location of stations in the Arabian Sea 
back to the surface. Upon retrieval of the gear, the sharks were weighed, photographed and carefully dissected. All organisms found were collected and stored in $5 \%$ buffered formalin for taxonomic identification. In the laboratory, images were projected to original size and the following information noted for each photograph: number, orientation and - whenever possible-size of all identifiable organisms and condition of the shark carcass. Film material used was Kodak Ektachrome 200 ASA Daylight (35 $\mathrm{mm} \times 30 \mathrm{~m}$ ).

To determine the structure of the background megafaunal community, photographic as well as TV camera surveys were carried out with the deep-towed photographic frame EXPLOS that is equipped with 2 Photosea 5000 still cameras and 2 Osprey 0111-6006 TV cameras. The gear was towed at approx. 0.5 knots. To photograph a known area, the still cameras were triggered upon contact of a bottom weight $1.30 \mathrm{~m}$ ahead of the instrument. At each station a series of approx. 300 photographs was taken, each covering $1.10 \mathrm{~m}^{2}$, and megafauna organisms were counted and measured on each frame. In addition, video surveys covering a larger area were carried out to yield estimates of bottom-dwelling fish densities. Here, the area covered was estimated using the densities of abundant non-mobile epifaunal organisms as determined from the bottom photographs. Film material used was the same as above. Specimens attached to the carcass upon retrieval and specimens caught in bottom trawls and fish traps (courtesy B. Martin and B. Christiansen, Hamburg) were used for species identification.

For macrourids and lysianassids, i.e. for those groups for which data on swimming speeds were available from the literature, abundance was also calculated from the time of first arrival at bait applying the relationship $\mathrm{n}=k t_{\mathrm{a}}{ }^{-2}$, where $k$ is a constant dependent on current speed and fish swimming speed (Priede \& Merrett 1996). A mean current speed of $0.03 \mathrm{~m} \mathrm{~s}^{-1}$ was assumed.

\section{RESULTS \\ WAST plain}

The shark carcass was retrieved largely intact and had lost $6 \mathrm{~kg}$ of weight. Long, deep grooves were chewed into the flesh at the back where the skin had been removed. In addition, flesh was gnawed off around the gill openings and the anus. Several small holes of 0.5 to $1 \mathrm{~cm}$ in diameter had been eaten into the skin and flesh ventrally. Upon retrieval of the carrion, several small amphipods were collected from the gill area. On the photographs, 3 groups of organisms were observed feeding on the bait: decapod shrimp, eelpouts (Zoarcidae) and lysianassid amphipods.

The first specimen of Plesiopenaeus armatus (Bate, 1881, Aristeidae) was present on the first picture taken at the seafloor, and thus had arrived within $20 \mathrm{~min}$. This species was present until the end of the deployment with up to 8 ind. frame $e^{-1}$ and regularly fed on tissue of the shark's back. During the first $2 \mathrm{~d}$ of the experiment, 2 to $4 P$. armatus regularly stayed on or near the carcass, but at the end of the 2 nd day their abundance declined and they occurred only occasionally. This decline may be related to the high number of zoarcids that had gathered on and around the carcass.

Zoarcids of the genus Pachycara appeared after $3 \mathrm{~h}$ and only a few individuals were present from 3 to $18 \mathrm{~h}$. The number of zoarcids then rose steadily to a maximum of 68 ind. photo ${ }^{-1}$ at 57 h (Fig. 2, Table 1). From 48 to $96 \mathrm{~h}$ a more or less constant number of approx. 50 ind. was present around the carrion; during the last day of the observation period mean abundance decreased slightly to 40 ind. The fish fed most heavily on the shark's back and after approx. $24 \mathrm{~h}$ several individuals had eaten themselves deep into the flesh, creating grooves. Many specimens appeared sluggish and often remained motionless in the vicinity of the

Table 1 Occurrence of scavengers as observed on time-lapse photographs of 2 shark carcasses placed on the seafloor in the deep Arabian Sea

\begin{tabular}{|c|c|c|c|c|c|c|c|c|}
\hline & \multicolumn{4}{|c|}{ WAST plain $4040 \mathrm{~m}$} & \multicolumn{4}{|c|}{ WAST top $1900 \mathrm{~m}$} \\
\hline & $\begin{array}{c}\text { First } \\
\text { occurrence }\end{array}$ & $\begin{array}{c}\text { Last } \\
\text { occurrence }\end{array}$ & $\begin{array}{c}\text { Peak } \\
\text { density }\end{array}$ & $\begin{array}{l}\text { Max. no. } \\
\text { image }^{-1}\end{array}$ & $\begin{array}{c}\text { First } \\
\text { occurrence }\end{array}$ & $\begin{array}{c}\text { Last } \\
\text { occurrence }\end{array}$ & $\begin{array}{c}\text { Peak } \\
\text { density }\end{array}$ & $\begin{array}{l}\text { Max no. } \\
\text { image }^{-1}\end{array}$ \\
\hline Lysianassidae & $40 \mathrm{~min}$ & $5 \mathrm{~d}$ & $21 \mathrm{~h}$ & 9 & & & & \\
\hline Zoarcidae & $5 \mathrm{~h}$ & $5 \mathrm{~d} 9 \mathrm{~h}$ & $2 \mathrm{~d} 9 \mathrm{~h}$ & 68 & $3 \mathrm{~h}$ & $21 \mathrm{~h}$ & - & 1 \\
\hline Aristeidae & $20 \mathrm{~min}$ & $5 \mathrm{~d} 9 \mathrm{~h}$ & $21 \mathrm{~h}$ & 8 & & & & \\
\hline Macrouridae & & & & & $50 \mathrm{~min}$ & $3 \mathrm{~d} 8 \mathrm{~h}$ & $2 \mathrm{~d} 1 \mathrm{~h}$ & 4 \\
\hline Lithodidae & & & & & $2 \mathrm{~h}$ & $3 \mathrm{~d} 8 \mathrm{~h}$ & & 2 \\
\hline
\end{tabular}



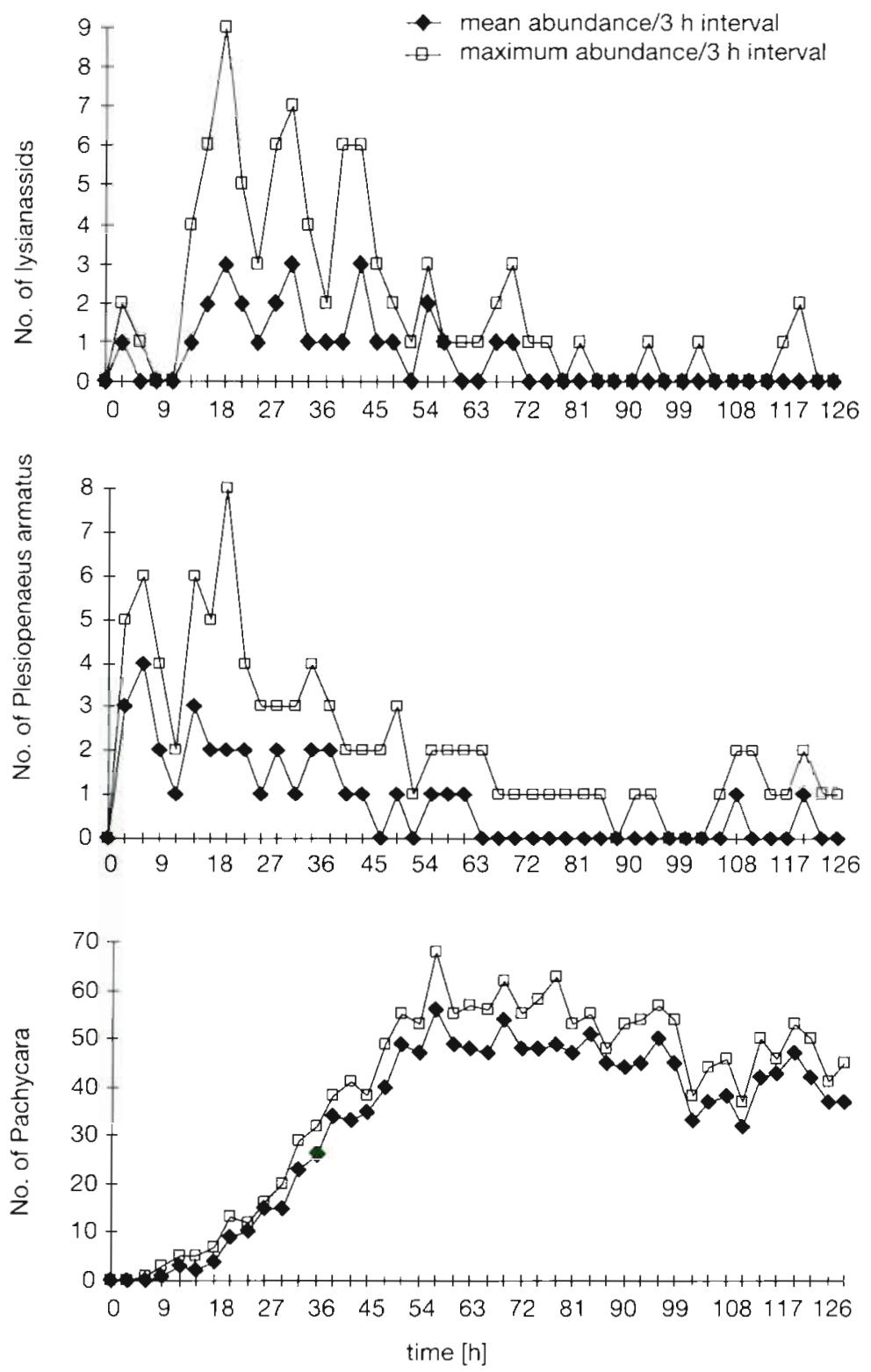

Fig. 2. Abundance of main scavengers at bait during the deployment at WAST plain, $4040 \mathrm{~m}$

bait over long periods of more than $1 \mathrm{~d}$ (roosting behaviour). The ventral holes in the shark carcass most likely stem from zoarcid feeding activity as they were always found at positions where an individual Pachycara specimen had been observed for long periods (>24 h).

Large (>1.5 cm) lysianassid amphipods (probably Eurythenes sp.; B. Christiansen pers. comm.) appeared at the bait within $40 \mathrm{~min}$. They were present regularly in low numbers during Days 1 and 2 (Fig. 2) and appeared to be actively feeding on the carcass. After $48 \mathrm{~h}$ lysianassid abundance declined, and after $72 \mathrm{~h}$ they appeared infrequently
The following specimens of lysianassids were collected from the carcass upon retrieval: Eurythenes gryllus (Lichtenstein, 1882) 5 ind.; Abyssorchomene abyssorum (Stebbing, 1888) 16 ind; and $A$. chevreuxi (Stebbing, 1906) 2 ind.

\section{WAST top}

At WAST top, the bait did not show strong feeding impacts upon retrieval after $4 \mathrm{~d}$; weight loss was approx. $1.5 \mathrm{~kg}$. The shark skin remained intact except where it had been removed prior to the experiment. On the time lapse photographs, rattails of the family Macrouridae and stone crabs (Lithodidae) were identified as major scavenging organisms (Fig. 3). In addition, 1 zoarcid was present for approx. $18 \mathrm{~h}$, and a member of the family Chimaeridae and 1 specimen of an, as yet, unidentified fish species were photographed once.

Macrouridae first appeared after $50 \mathrm{~min}$ and occurred steadily on approx. $1 / 3$ of the photographs until the end of the observation period. Altogether, 227 rattails were counted on 174 (of 480) pictures. They were frequently observed 1 feeding on the back of the shark. Since weight loss of the bait was small, the macrourids possibly fed on small amphipods invisible on the photographs. However, although no respective observations were made, the net may have constrained the feeding behaviour of large macrourids that can tear off chunks of meat and swim away with it. It was not possible to identify individual rattails, but the varying size of consecutively photographed fish indicates that individual specimens did not stay long near the carrion.

Lithodidae: 5 specimens of deep-sea stone crabs Neolithes alcocki Dawson \& Yaldwyn 1985 and Neolithodes vinogradovi McPherson 1988 (Lithodidae) were attracted to the bait, the first appearing within $2 \mathrm{~h}$. Two small stone crabs appeared once each. Three large specimens ( $2 \mathrm{~N}$. vonogradovi, $1 \mathrm{~N}$. alcocki) with a carapace diameter of 18 to $19 \mathrm{~cm}$ could be identified individually. During $70 \%$ of the observation period, 1 of these 3 specimens was sitting on the carcass, frequently feeding actively. Usually 1 specimen stayed for up to $10 \mathrm{~h}$ at a time, hardly changing its position. The crabs regularly changed their position before they disappeared and 


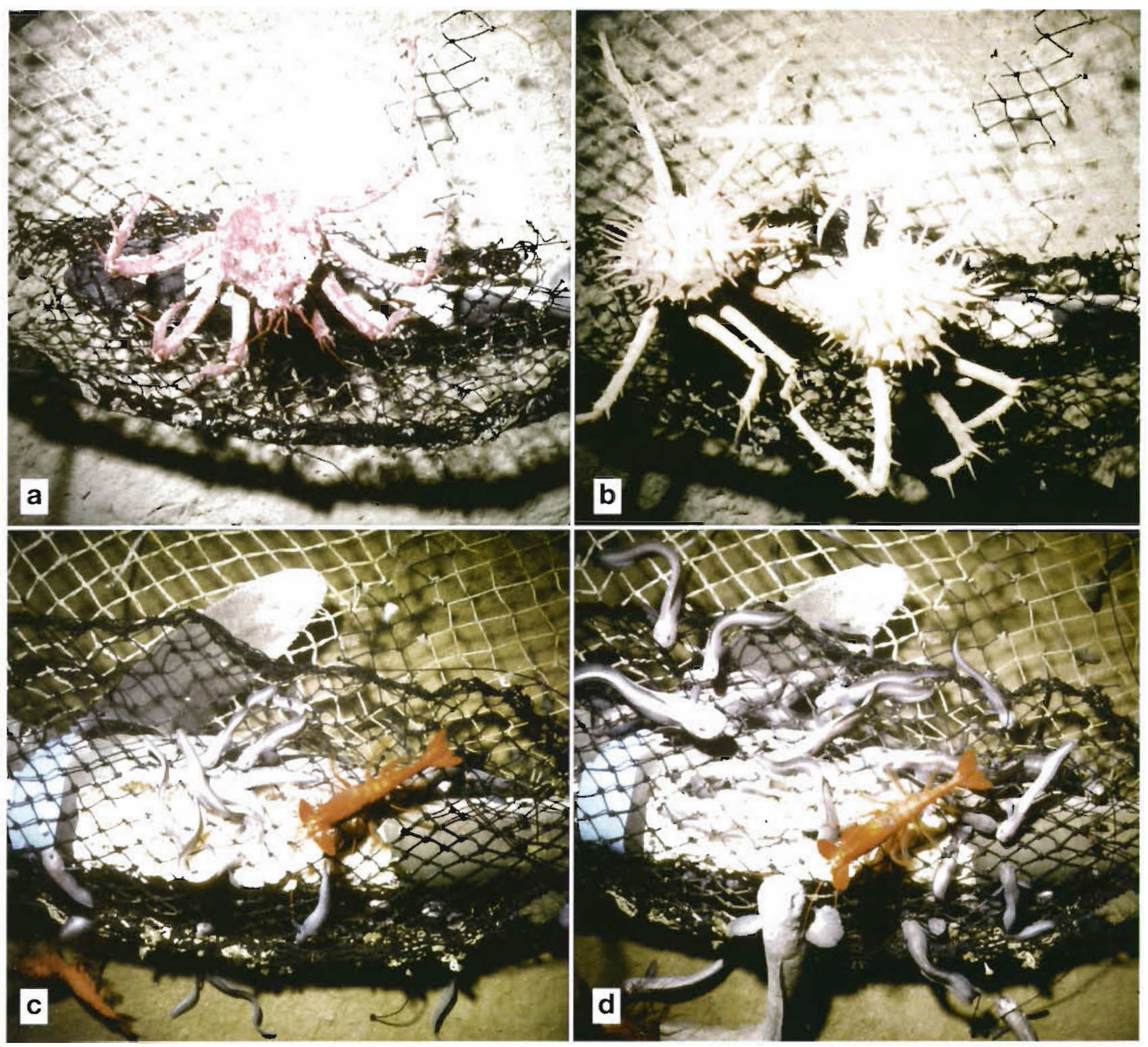

Fig. 3. Dominant bait attending scavengers in the deep Arabian Sea. (a, b) WAST top after 1.5 and 3 d; (c, d) WAST plain after 1.5 and $3 \mathrm{~d}$

were replaced in the field of view by another individual arriving from the departee's direction. Two specimens were seen on the same picture in only 1 or 2 consecutive photographs. This might indicate that Neolithodes sp. does not tolerate other individuals feeding simultaneously on their prey. It is not known whether the 3 specimens stayed in the vicinity of the bait during deployment.

Upon retrieval of the bait, 15 specimens of Abyssorchomene abyssorum (Stebbing, 1888) were collected from the gill area. Because of their small size $(<1.0 \mathrm{~cm})$ and the penetration of individuals into the carcass, no counts were made from the photographs.

\section{Abundance of megaiauna in the background community}

At WAST top, the most abundant megafaunal organisms detected in bottom photographs were undetermined natant decapods (114 ind. $1000 \mathrm{~m}^{-2}$ ) and brittle stars (21 ind. $1000 \mathrm{~m}^{-2}$ ). Abundance of macrourid fish estimated from TV camera surveys was 21 ind. $1000 \mathrm{~m}^{-2}$ (Table 2). At WAST plain, brittle stars were the only megafaunal organisms observed in bottom photographs and, with 100 ind $1000 \mathrm{~m}^{-2}$, were 5 times as abundant as at WAST top. Abundance of both zoarcid fish and Plesiopenaeus armatus estimated from 
Table 2. Abundance of megafaunal taxa in the background community at 1900 and $4040 \mathrm{~m}$ determined by photographic and video surveys

\begin{tabular}{|lrrrr|}
\hline & $\begin{array}{c}\text { WAST plain } 4040 \mathrm{~m} \\
\text { Still camera } \\
\text { (Ind. } 1000 \mathrm{~m}^{-2} \text { ) }\end{array}$ & \multicolumn{2}{c|}{$\begin{array}{c}\text { WAST top } 1900 \mathrm{~m} \\
\text { Still camera } \\
\text { (Ind. 1000 } \mathrm{m}^{-2} \text { ) }\end{array}$} \\
\hline Aristeidae & 0 & 1 & 114 & 110 \\
Ophiuridae & 100 & 100 & 21 & 22 \\
Macrouridae & 0 & 0 & 6 & 21 \\
Zoarcidae & 0 & 1 & 0 & 0 \\
\hline
\end{tabular}

video surveys was 1 ind. $1000 \mathrm{~m}^{-2}$ (Table. 2). As zoarcids never reacted to the presence of the sled unless hit by the ground weight, these abundance estimates are assumed to be reliable. P. armatus, however, was observed to swim away from the sled actively, and thus densities are probably underestimated. This is in agreement with the fact that large numbers of $P$. armatus were caught in bottom trawls (B. Christiansen pers. comm.).

Abundances for lysianassids and macrourids calculated from time of first arrival were $216 \mathrm{~km}^{-2}$ and $97 \mathrm{~km}^{-2}$, respectively.

\section{Area affected}

\section{WAST top}

As neither the decapod shrimp nor the brittle stars were attracted to the bait, the area from which scavengers were drawn to the carcass can only be inferred from macrourid abundance. If it is assumed that the rattails photographed represent 227 different ind., and that the population density of 21 ind. $1000 \mathrm{~m}^{-1}$ obtained from the TV camera surveys is realistic, this is equivalent to the population of approx. $10000 \mathrm{~m}^{2}$.

\section{WAST plain}

Due to the large number of eelpouts and overlapping arrivals and departures after $48 \mathrm{~h}$, it was in most cases impossible to recognize individual eelpouts. However, individual identification was possible for some very large specimens as well as for specimens arriving between 0 and $24 \mathrm{~h}$ due to their low activity, size differentials and constant bottom contact. All the large individuals stayed for several days, and none of the first arrivals left before crowding prevented further identification. Assuming that (1) all specimens that arrived between 0 and $48 \mathrm{~h}$ stayed until the peak density of 70 ind. was reached in full and (2) all specimens present between 48 and $129 \mathrm{~h}$ stayed at least $24 \mathrm{~h}$, between 70 and 222 ind. were drawn to the carcass from 70000 to $220000 \mathrm{~m}^{2}$ at the deep station.

\section{DISCUSSION}

\section{Species composition of the benthopelagic Arabian Sea scavenger community}

The most striking pattern of assemblage composition is the rare occurrence of the characteristic, highly mobile necrophages of other deep-sea areas. The ubiquitous, giant lysianassid amphipod Eurythenes gryllus is usually readily attracted to bait and can be the main consumer of large carcasses (Jones et al 1998). This species is well adapted to the exploitation of large but unpredictable food falls. It has the capability to store disproportionately large meals compared to shallow water forms (Dahl 1979), ingesting 30 to $75 \%$ of its body weight at a time (Hargrave 1985, Hargrave et al. 1994), and is known to feed to satiation and then continue to feed at short intervals, a feeding strategy known as 'tank-topping' (Smith 1985). In the deep western Arabian Sea, however, amphipods were rare they were completely absent at $1900 \mathrm{~m}$ and only occurred in low numbers at $4040 \mathrm{~m}$ depth. As amphipod numbers declined when fish became more abundant, it is possible that the presence of a large number of zoarcids discouraged lysianassids from approaching the carcass. Fish might have concealed the amphipods, but it is assumed that the large number of amphipods necessary to consume a substantial part of the bait would not have gone unnoticed. However, Smith (1985) reports lysianassids of the genus Orchomene from the Santa Catalina Basin (SCB) to be little affected by high hagfish abundances.

Similarly, macrourid fish were absent at the deep station in the Arabian Sea and only occurred in low numbers at $1900 \mathrm{~m}$. These fish are known to use unpredictable food sources, but the 'sit and wait' strategy postulated on theoretical energetic considerations has been questioned by Priede et al. (1991), who found abyssal rattails to be active foragers. Their movement greatly enhances the probability of encountering food falls and more than compensates for the energetic cost of locomotion

Instead, in our experiments, the eelpout Pachycara sp. and the decapod shrimp Plesiopenaeus armatus were the main consumers of bait at abyssal depth, and the stone crab Neolithodes sp. dominated at our seamount station. Eelpouts, the characteristic sit-andwait predators of higher latitude shallow waters (Gage \& Tyler 1991) are well known to extend into the deepsea. Two-line eelpouts (Bothrocara brunneum) from 
the eastern North Pacific are generally observed hovering within half a meter of the bottom and feed almost exclusively on benthopelagic crustaceans, mainly shrimps and mysids (Ferry 1997). Thurston et al. (1995) observed the zoarcid Pachycara bulbiceps in the vicinity of bait deployed in the Porcupine Abyssal Plain $(4800 \mathrm{~m})$, but it was never seen to touch the bait. Hence, it was concluded that $P$. bulbiceps feed either on fragments detached by other fish or on the numerous necrophagous amphipods. However, the bait was inaccessible from the sea floor and as Pachycara sp. showed constant bottom contact in our experiments, this might have prevented the animals from reaching the carrion. It is assumed that the grooves stem from Pachycara sp. feeding activity, as specimens were observed in the appropriate position for periods of more than $1 \mathrm{~d}$, gradually descending into the shark tissue. The presence of an amphipod in the stomach of a Pachycara sp. specimen (F. Janssen pers. comm.), however, confirms that this species, too, can feed on benthopelagic crustaceans. The possibility that the grooves were created by amphipods that were in turn followed and eaten by zoarcids is ruled out by the low numbers of Eurythenes gryllus observed at bait and the size of the grooves (up to $20 \mathrm{~cm}$ long). The second abundant species at abyssal depth was the aristeid $P$. armatus. As indicated by the presence of phytodetritus in the gut of $P$. armatus (Thurston et al. 1995), this species, too, is a facultative necrophage that also relies on other food sources. Thus, facultative necrophages appear to be the main consumers of large carrion in the abyssal western Arabian Sea, and specialised and highly mobile scavengers seem to be of minor importance.

Despite the worldwide distribution of e.g. scavenging lysianassid amphipods (Ingram \& Hessler 1983), striking latitudinal differences with respect to the organisms attracted to bait parcels have been reported by Thurston et al. (1995). Their baited camera experiments were conducted at $21^{\circ} \mathrm{N}, 31^{\circ} \mathrm{N}$ and $48^{\circ} \mathrm{N}$ in the North Atlantic, and whereas fish dominated at the northernmost locality (PAP), Plesiopenaeus armatus dominated at the stations further south (MAP, OLIGO) but was almost absent at PAP. Latitudinal variation was also detected in the macroplankton: micronekton ratio (Angel \& Hargreaves 1992) as well as in abyssal fish assemblages (Merrett 1987) and is related to the fact that the stations differ with respect to the vertical flux pattern of organic material. Whereas the overall organic input to the seafloor is similar at all 3 sites, PAP experiences a strong seasonal phytodetritus pulse that is absent at MAP (Rice et al. 1994) and probably OLIGO. The authors conclude that higher numbers of suitable food organisms at PAP sustain a large population of large, macrophagous ben- thopelagic species such as Coryphaenoides armatus and Histiobranchus bathybius but not at MAP, where mainly small, microphagous, benthic species occur. $P$. armatus is assumed to feed on large food falls where fish densities are low and on other food sources where fish are abundant. In this context, this study would indicate that in the abyssal Arabian Sea densities of the macrophage Pachycara sp. are so low that $P$. armatus is still able to take advantage of large food falls.

\section{Number of scavengers attracted to bait as an index of scavenger abundance}

Several authors have attempted to estimate the abundance of fish from baited-camera data. Hydrodynamic models have attempted to relate the cumulative number of scavengers attracted to the field of attraction, calculated by means of odour plume dispersion models (Sainte-Marie \& Hargrave 1987). However, the area of attraction ultimately depends on the chemosensory thresholds of the individual scavenger species, which have hitherto not been measured in an objective way. For grenadiers in the Pacific Ocean, Priede et al. (1990) found an inverse relationship between numbers seen in photographs and prevailing abundance.

However, Priede \& Merrett (1996) found that times of first arrival of the macrourid Coryphaenoides armatus correlated well with the data of fish density obtained from extensive trawling, through the relationship $\mathrm{n}=k t_{\mathrm{arr}}{ }^{-2}$, where $k$ is a constant dependent on current speed and fish swimming speed. For the macrourids that were attracted to the carcass in this study, however, the abundance calculated applying the equation of Priede \& Merrett (1996) is considerably lower than that obtained from the video surveys, indicating that only a small part of the macrourid population was attracted by the bait. This supports the view of Priede \& Merrett (1998), who conclude that, desirable as it would be to obtain a fishery independent index of abundance, 'such methods should only be used after proper validation and with a good understanding of the species behaviour'-which, for most deep-sea species, is not yet available.

\section{Importance of large food falls for the benthic community}

At bathyal depth in the SCB, both the rare and highly mobile as well as several other common epifaunal species profit directly from the occurrence of nekton falls. The ophiuroid Ophiophthalmus normani, the dominant megabenthic species in the background 
epifaunal assemblage, was most strongly attracted to the carrion, attaining densities of $700 \mathrm{~m}^{-2}$ in aggregations containing thousands of individuals (Smith 1985). In the Arabian Sea, ophiuroids (WAST plain) and ophiuroids and shrimps (WAST top) were by far the most abundant epifaunal organisms in the background community. However, none of these were attracted to the bait. The free niche created by the absence of true necrophages is obviously not occupied by other epifaunal organisms with the exception of some equally rare facultative necrophages. This is mirrored in low consumption rates: at the $4040 \mathrm{~m}$ station, $0.5 \mathrm{~kg} \mathrm{~d}^{-1}$ of soft tissue were consumed, compared to 1 to $10 \mathrm{~kg} \mathrm{~d}^{-1}$ at a similar depth in the North Atlantic (Jones et al. 1998). It should, however, be kept in mind that this implies the comparison of different types of bait. Jannasch (1978) reports striking differences in the consumption of tuna and shark meat at $3600 \mathrm{~m}$ depth.

The facultative necrophages that consumed most of the bait occur in low densities, which implies that the area from which organisms were drawn to the carcass - and thus the area to which they disperse after feeding-is large. For the seamount station it is approx. 10 times, for the abyssal station 70 to 200 times, greater than estimated for the SCB. Via excretion and defaecation by the dispersing organisms, this area experiences an indirect organic enrichment from the food fall. Thus, contrary to other deep-sea areas where fish and invertebrate scavengers efficiently consume and disperse a carcass, the indirect effects on the benthic community are possibly very important in the Arabian Sea: a considerable proportion of the carrion might remain for direct utilization by the sediment community in the western Arabian Sea and a much larger area might profit from organic enrichment.

In conclusion, the consumption and dispersal pattern of large food falls in the abyssal western Arabian Sea differs considerably from other deep-sea areas with respect to the species attracted and their succession as well as to turnover rate and dispersal of the carrion. However, care has to be taken when comparing sites, literally oceans apart, as it is often not known how typical each site is of even the broader locality, let alone of an ocean in general. A series of further experiments to be conducted during the next BIGSET cruise to the Arabian Sea will be needed to clarify whether this holds true for other areas in the deep Arabian Sea with lower organic input and whether the same consumers are attracted by various types of bait.

Acknowledgements. Thanks are due to captain H. Papenhagen and his crew from RV 'Sonne' Taxonomic identifications were kindly carried out by $\mathrm{H}$. G. Andres (Amphipoda), B. Martin (Zoarcidae), E. Macpherson (Lithodidae) and M. Türkay (Aristeidae and Lithodidae). The manuscript benefitted from the comments of Dr I. G. Priede, Dr R. Koppel- mann, F. Janssen and 3 anonymous referees. This work was funded by the Bundesministerium für Bildung, Wissenschaft, Forschung und Technologie and is a publication of the joint research programme BIGSET.

\section{LITERATURE CITED}

Angel MV, Hargreaves PM (1992) Large-scale patterns in the distribution of planktonic and micronectic biomass in the northeast Atlantic. ICES J Mar Sci 49:403-411.

Chevreux E (1900) Amphipodes provenant des campagnes de l'Hirondelle (1885-1888). Résult Camp Sci Prince Albert 116:1-195

Christiansen B (1996) Bait-attending amphipods in the deep sea: a comparison of three localities in the north-eastern Atlantic. J Mar Biol Assoc UK 76:345-360

Dahl E (1979) Deep-sea carrion feeding amphipods: evolutionary patterns in niche adaptation. Oikos 33:167-175

Ferry LA (1997) Food habits of the two-line eelpout (Bothrocara brunneum: Zoarcidae) at two deep-sea sites in the eastern North Pacific. Deep-Sea Res 44(3):521-531

Gage JD, Tyler PA (1991) Deep-sea biology. A natural history of organisms at the deep-sea floor. Cambridge University Press, Cambridge

Haake B, Ittekkot V, Rixen $T$, Ramaswamy V, Nair RR, Curry WB (1993) Seasonality and interannual variability of particle fluxes to the deep Arabian Sea. Deep-Sea Res 40(7): $1323-1344$

Hargrave BT (1985) Feeding rates of abyssal scavenging amphipods (Eurythenes gryllus) determined in situ by time-lapse photography. Deep-Sea Res 32(4):443-450

Hargrave BT, Prouse NJ, Phillips GA, Cranford PJ (1994) Meal size and sustenance time in the deep-sea amphipod Eurythenes gryllus collected from the Arctic Ocean. DeepSea Res 41(10): 1489-1508

Hargrave BT, Phillips GA, Prouse NJ, Cranford PJ (1995) Rapid digestion and assimilation of bait by the deep-sea amphipod Eurythenes gryllus. Deep-Sea Res 42(11/12): 1905-1921

Heezen BC. Hollister CD (1971) The face of the deep. Oxford University Press, New York

Hessler RR, Isaacs JD, Mills EL (1972) Giant amphipods from the abyssal Pacific Ocean. Science 175:636-637

Hessler RR, Ingram CL, Yayanos AA, Burnett BR (1978) Scavenging amphipods from the floor of the Philippine Trench. Deep-Sea Res 25:1029-1047

Ingram CL, Hessler RR (1983) Distribution and behaviour of scavenging amphipods from the central North Pacific. Deep-Sea Res 30(7A):683-706

Ingram CL, Hessler RR (1987) Population biology of the deepsea amphipod Eurythenes gryllus: inferences from instar analyses. Deep-Sea Res 34(12):1889-1910

Jannasch HW (1978) Experiments in deep-sea microbiology. Oceanus 21:50-57

Jones EG, Collins MA, Bagley PM, Addison S, Priede IG (1998) The fate of cetacean carcasses in the deep sea: observations on consumption rates and succession of scavenging species in the abyssal north-east Atlantic Ocean. Proc R Soc Lond B 265:1119-1127

Merrett NR (1987) A zone of faunal change in assemblages of abyssal demersal fish in the eastern North Atlantic: a response to seasonality in production? Biol Oceanogr 5: $137-151$

Priede IG, Merrett NR (1996) Estimation of abundance of abyssal demersal fishes; a comparison of data from trawls and baited cameras. J Fish Biol 49:207-21.6 
Priede IG, Merrett NR (1998) The relationship between numbers of fish attracted to baited cameras and population density: studies on demersal grenadiers Coryphaenoides (Nematonurus) armatus in the abyssal NE Atlantic Ocean. Fish Res 36:133-137

Priede IG, Smith KLJ, Armstrong JD (1990) Foraging behaviour of abyssal grenadier fish: inferences from acoustic tagging and tracking in the North Pacific Ocean. DeepSea Res 37(1):81-101

Priede IG, Bagley PM, Armstrong JD, Smith KLJ, Merrett NR (1991) Direct measurements of active dispersal of food falls by deep-sea demersal fishes. Nature 351:647-649

Priede IG, Bagley PM, Smith A, Creasey S, Merrett NR (1994) Scavenging deep demersal fishes of the porcupine seabight, NE Atlantic: observations by baited camera, trap and trawl. J Mar Biol Assoc UK 74:481-498

Priede IG, Addison S, Bradley S, Bagley PM, Gray P, Yau C, Rolin JF, Blandin J, LeGrand J, Khripounoff A, Vangriesheim A, Cremer A, Witte U, Pfannkuche O, Tengberg $A$, Hulth $S$, Hall $P$, Helder $W$, van Weering $T$, Duineveld G (1998) Autonomous deep-ocean lander vehicles; modular approaches to design and operation. Proc

Editorial responsibility: Otto Kinne (Editor),

Oldendorf/Luhe, Germany
OCEANS '98 IEEE, Vol 2, Nice, 28 September-1 October p 1120-1125

Rice AL, Thurston $\mathrm{MH}_{4}$ Bett BJ (1994) The IOSDL DEEPSEAS programme: introduction and photographic evidence for the presence and absence of a seasonal input of phytodetritus at contrasting abyssal sites in the north-eastern Atlantic. Deep-Sea Res 41:1305-1320

Sainte-Marie B, Hargrave BT (1987) Estimation of scavenger abundance and distance of attraction to bait. Mar Biol 94:431-443

Smith CR (1985) Food for the deep sea: utilization, dispersal, and flux of nekton falls at the Santa Catalina Basin floor Deep-Sea Res 12(4):417-442

Smith CR (1986) Nekton falls, low-intensity disturbance and community structure of infaunal benthos in the deep sea. J Mar Res 44:567-600

Stockton WL, DeLaca TE (1982) Food falls in the deep sea occurrence, quality, and significance. Deep-Sea Res 29(2A): $157-169$

Thurston HM, Bett BJ, Rice AL (1995) Abyssal megafaunal necrophages: latitudinal differences in the Eastern North Atlantic Ocean. Int Rev Ges Hydrobiol 80(2):267-286

Submitted: November 17, 1998; Accepted: February 9, 1999 Proofs received from author(s): June 10, 1999 